\title{
KOLONIZACJA I URBANIZACJA TURYSTYCZNA POLSKIEGO WYBRZEŻA NA PRZYKLADZIE MIEJSKIEGO OBSZARU FUNKCJONALNEGO KOŁOBRZEG
}

\begin{abstract}
Abstrakt: W artykule wskazano czynniki, kierunki i skalę rozwoju procesów kolonizacyjnych i urbanizacyjnych Nadmorskiego Obszaru Funkcjonalnego (NOF) Kołobrzeg z uwzględnieniem budowanych mieszkań, domów, apartamentów, hoteli i rozbudowy systemu komunikacyjnego.

Słowa kluczowe: miejski obszar funkcjonalny, kolonizacja turystyczna, urbanizacja turystyczna, teoria progowa.

\section{TOURIST COLONIZATION AND URBANIZATION ON THE POLISH COAST ON THE EXAMPLE OF FUNCTIONAL URBAN AREA OF KOLOBRZEG}

Abstract: The author presented factors, directions and scale of the colonization and urbanization of the Kolobrzeg Seaside Functional Area (SFA) including the building of flats, houses, apartments, hotels and the expansion of the communications system (as FUA - Functional Urban Area). Keywords: functional urban area, space tourism, tourism urbanization, threshold theory.
\end{abstract}

\section{WSTĘP}

Polskie wybrzeże Morza Bałtyckiego od wielu lat jest obszarem intensywnego rozwoju funkcji turystycznych i wypoczynkowych. Warunki klimatyczne oraz liczne ograniczenia przestrzenne i przyrodnicze są przyczyną klasycznego zjawiska sezonowości, co sprawia, że prawie całe polskie wybrzeże jest intensywnie wykorzystywane tylko przez 60-75 dni w roku. Pewną szansą na wydłużenie długości sezonu turystycznego jest rozwój funkcji uzdrowiskowych oraz koncentracja działalności turystycznej w rozbudowanych wielofunkcyjnych ośrodkach miejskich. Warunki takie spełnia obecnie wyłącznie Trójmiasto oraz dwa największe polskie uzdrowiska nadmorskie - Kołobrzeg i Świnoujście. Tylko tam rozwój funkcji turystycznych ma już charakter całoroczny, co dodatkowo wiąże się z dobrą dostępnością komunikacyjną tych miast. Mniejsze uzdrowiska (Ustka, Kamień Pomorski, Dąbki) i inne ośrodki turystyczne (np. Międzyzdroje, Darłowo, Łeba, Hel), z powodu niewielkiego potencjału demograficzno-gospodarczego oraz utrudnionej dostępności, nie są tak atrakcyjnym miejscem dla rozwoju komercyjnych funkcji turystycznych $\mathrm{w}$ porównaniu z Trójmiastem, Kołobrzegiem i Świnoujściem. Celem autora artykułu była charakterystyka procesów kolonizacyjnych i urba- nizacyjnych Nadmorskiego Obszaru Funkcjonanego Kołobrzeg tworzącego klasyczny miejski obszar funkcjonalny (Functional Urban Area).

\section{UWARUNKOWANIA DECYDUJACE O SKALI PROCESÓW KOLONIZACYJNYCH I URBANIZACY]NYCH}

Nadmorskie obszary turystyczne Trójmiasta, Kołobrzegu i Świnoujścia są bardzo silnie zróżnicowane pod względem demograficznym, społeczno-gospodarczym i przestrzenno-funkcjonalnym. W Trójmieście funkcje turystyczne są najsilniej zróżnicowane i rozbudowane, przy czym i tak mają one charakter uzupełniający wobec głównych funkcji portowo-przemysłowych, usługowo-transportowych i biznesowo-administracyjnych, skupiając się w Gdańsku (turystyka krajoznawcza, kulturowa, biznesowa i konferencyjna), Sopocie (turystyka wypoczynkowo-uzdrowiskowa) i Gdyni (turystyka krajoznawcza i kulturowa), miastach o bardzo dobrej dostępności komunikacyjnej. W Świnoujściu rozwija się turystyka wypoczynkowo-uzdrowiskowa, przy jednoczesnym występowaniu istotnych ograni- 
czeń przestrzenno-funkcjonalnych (44 wyspy, port morski, obszary chronione) z ograniczoną dostępnością komunikacyjną wnętrza tamtejszej przestrzeni turystycznej, co znacznie ogranicza skalę dalszego rozwoju potencjału turystycznego tego miasta (przeprawa promowa). Dodatkowym czynnikiem ograniczającym jest brak klasycznego obszaru funkcjonalnego wokół Świnoujścia z powodu jego położenia fizycznogeograficznego. Spośród tych trzech najważniejszych nadmorskich obszarów turystycznych polskiego wybrzeża, Kołobrzeg, tworzący jednocześnie Nadmorski Obszar Funkcjonalny (NOF) rozwinął na największą skalę funkcje uzdrowiskowo-wypoczynkowe uzupełniając je funkcjami usługowo-portowymi (Lider Projekt 2014). Bardzo silne procesy kolonizacyjne i urbanizacyjne występujące w Kołobrzegu i jego zapleczu (gminy Kołobrzeg i Ustronie Morskie) sprawily, że wykształcił się tu silnie zurbanizowany i skolonizowany obszar, obejmujący ponad $30 \mathrm{~km}$ wybrzeża. Pod względem przestrzenno-funkcjonalnym NOF promieniuje również na tereny sąsiednich gmin, co objawia się wysokim natężeniem dojazdów do pracy i szkót, rozwojem budownictwa rezydencjonalnego oraz lokalizacją uciążliwych funkcji przemysłowych i komunalnych w gminach zewnętrznych (gminy Trzebiatów, Rymań, Gościno, Dygowo). Obecnie jest to trzecie obok Warszawy i Krakowa $\mathrm{w}$ Polsce centrum ruchu turystycznego pod względem liczby udzielonych osobonoclegów według danych GUS (przy zastrzeżeniu, że w przypadku uwzględnienia drobnej prywatnej bazy noclegowej byłoby to największe centrum - Miedziński 2012a).

Realizowana obecnie rozbudowa układu komunikacyjnego, poprzez budowę trasy dojazdowej do portu morskiego (obwodnicy śródmieścia Kołobrzegu) będącej docelowo końcowym odcinkiem drogi ekspresowej S-11 oraz budowa drugiej drogi ekspresowej S-6 (drugiej obwodnicy Kołobrzegu) sprawią, że będzie to najlepiej skomunikowany ośrodek uzdrowiskowy w Polsce (Komornicki 2015). Dodatkowymi czynnikami wzmacniającymi tę dostępność komunikacyjną jest szybkie połączenie kolejowe typu Pendolino w relacji Kołobrzeg-Trójmiasto-Warszawa-Kraków, działające lotnisko sportowo-turystyczne Kołobrzeg-Bagicz oraz przygotowywany do budowy dworzec morski, z nabrzeżem promowym. Należy podkreślić, że budowane obecnie drogi ekspresowe S-6 i S-11 na odcinku od Koszalina do Kołobrzegu przebiegają w odległości od $1 \mathrm{~km}$ do 8-9 km od linii brzegowej Morza Bałtyckiego („Program budowy dróg...” 2015).
Tak dobra docelowa dostępność komunikacyjna w połączeniu z realizacją założeń polityki transportowej MOF Kołobrzeg i strategii rozwoju Koszalińsko-Kołobrzesko-Białogardzkiego Obszaru Funkcjonalnego (w ramach zintegrowanych inwestycji terytorialnych województwa zachodniopomorskiego) przyczyniła się do bardzo silnych procesów kolonizacyjnych i urbanizacyjnych na obszarze MOF Kołobrzeg. Dodatkowym czynnikiem rozwojowym jest status największego polskiego uzdrowiska i centrum SPA oraz największego obok Trójmiasta rynku nieruchomości i rynku budowlanego na polskim wybrzeżu (Miedziński 2015b).

\section{MOŻLIWOŚCI ROZWOJU PRZESTRZENNEGO I KOMUNIKACYJNEGO MOF KOŁOBRZEG}

Zmiany przestrzenne i funkcjonalne oraz bardzo duże inwestycje komunikacyjne zbliżają ten obszar do przekroczenia kluczowego progu rozwojowego (Kozłowski 1974, Malisz 1971), co będzie jednoznaczne z możliwym awansem Kołobrzegu z grupy miast o znaczeniu subregionalnym (KPZK 2030) do grupy miast o znaczeniu regionalnym. Kolejnym czynnikiem wzrostu znaczenia Kołobrzegu w sieci osadniczej może być poszerzenie granic administracyjnych miasta (Miedziński 2012b) i włączenie do niego obu sąsiednich gmin nadmorskich (Kołobrzeg i Ustronie Morskie). Taki rozwój przestrzenny Kołobrzegu doprowadziłby do powstania tu miasta (powiatu grodzkiego?) liczącego (wg obecnych danych) ponad 61 tys. mieszkańców z ponad 100 tys. miejsc noclegowych (wg danych GUS -27 tys.).

Nadmorski Obszar Funkcjonalny Kołobrzeg zwłaszcza w sezonie letnim cechuje bardzo silne przeciążenie systemu komunikacyjnego i dotkliwe problemy transportowe (Miedziński 2015b). Znaczne sezonowe zaludnienie tego NOF obejmujące ludność i turystów pozwala zakwalifikować Kołobrzeg do grona miast mających podobne trudności komunikacyjne jak np. Zielona Góra, Olsztyn czy Rzeszów, gdzie realizowane są poważne inwestycje komunikacyjne. Dlatego opracowany został dokument „Polityka transportowa Nadmorskiego Obszaru Funkcjonalnego Kołobrzeg", którego autorzy wskazują konieczność rozpoczęcia prac studialnych nad koncepcją budowy tramwaju dwusystemowego, który docelowo usprawniłby funkcjonowanie transportu pasażerskiego Miejskiego Obszaru Fun- 


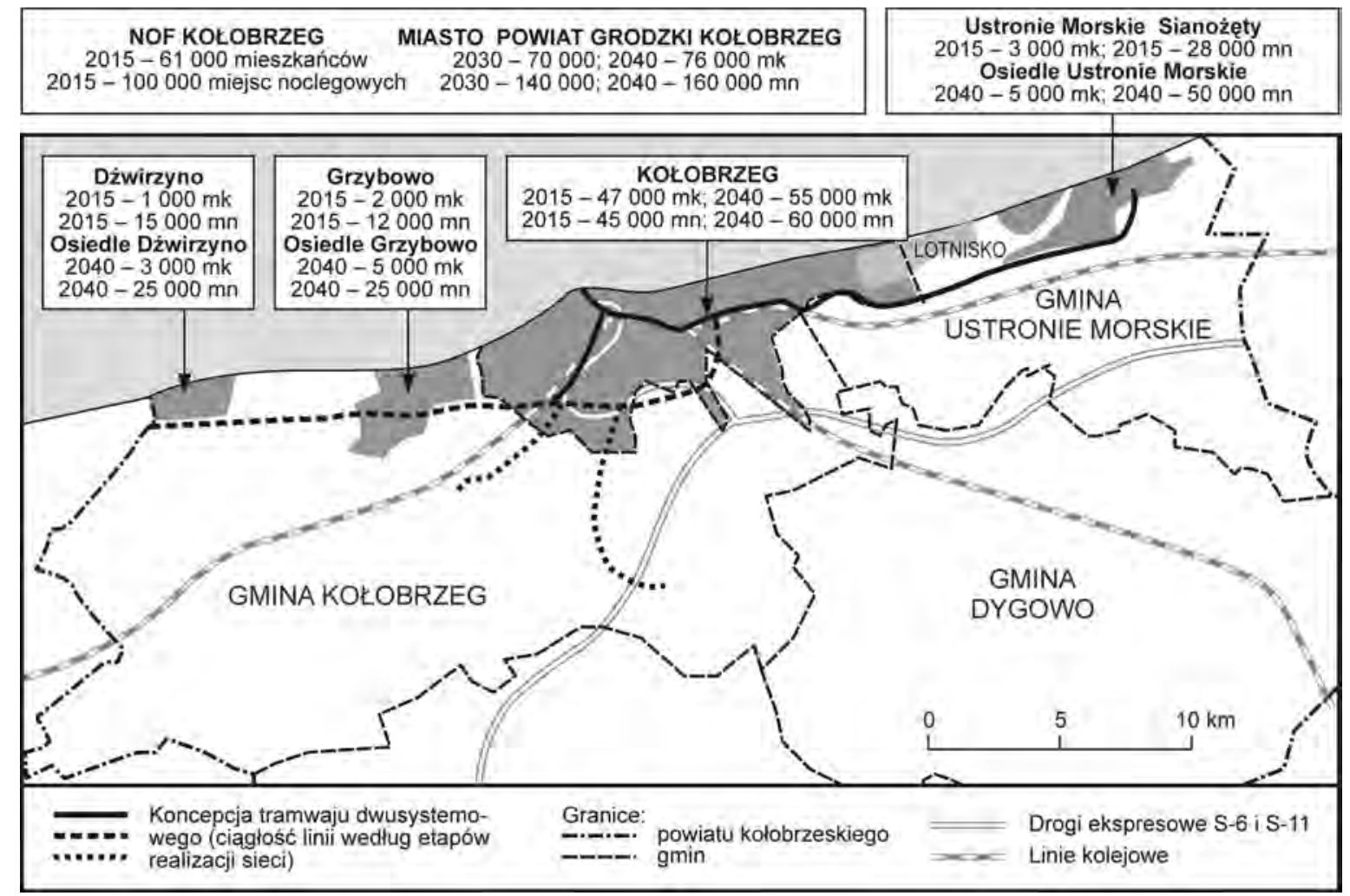

Rys. 1. Rozwój koncepcyjny budowy sieci tramwaju dwusystemowego na obszarze NOF Kołobrzeg w perspektywie do roku 2030 i na kierunek do 2040

Źródło: opracowanie własne na podstawie założeń „Polityki transportowej NOF Kołobrzeg”

kcjonalnego Kołobrzeg (Franek 2015). Koncepcja ta jest efektem szybkiego rozwoju przestrzennego i funkcjonalnego NOF Kołobrzeg oraz gwałtownie postępujących procesów kolonizacyjnych i urbanizacyjnych jego przestrzeni turystycznej (Miedziński 2015a). W przypadku faktycznego połączenia Kołobrzegu i obu sąsiednich gmin w jedno miasto - powiat grodzki Kołobrzeg - powstałby największy po Trójmieście obszar zurbanizowany polskiego wybrzeża, o długości ponad $30 \mathrm{~km}$ (Miedziński 2012b) (rys. 1).

Proponowana koncepcja budowy tramwaju dwusystemowego w NOF Kołobrzeg wynika z możliwej skali rozwoju potencjału ludnościowego oraz dalszego wzrostu pojemności ogólnodostępnej bazy noclegowej (Franek 2015). Obecna liczba ludności (2015 r. - 61 tys.) może się zwiększyć do 70 tys. w 2030 r. i 75 tys. osób w 2040 r. Pojemność bazy noclegowej, wynosząca w 2015 r. 100 tys. miejsc noclegowych, może osiągnąć 140 tys. miejsc w 2030 r. i 160 tys. miejsc w 2040. Łączna pojemność turystyczna NOF Kołobrzeg, wynosząca w 2015 r. 161 tys. osób, może wzrosnąć do 210 tys. w 2030 r. i 235 tys. osób w 2040. Do tego czasu przewozy pasażerskie $\mathrm{w}$ NOF Kołobrzeg mogłyby być $\mathrm{w}$ znaczący sposób realizowane $\mathrm{w}$ ramach nowego szynowego środka transportu, czyli tramwaju dwusystemowego. Potwierdzeniem konieczności rozważenia wprowadzenia tego środka transportu do NOF Kołobrzeg jest skala obecnych inwestycji oraz rosnąca liczba ludności i miejsc noclegowych.

\section{PROCESY KOLONIZACYJNE I URBANIZACY]NE NOF KOŁOBRZEG}

Kolonizacja i urbanizacja turystyczna atrakcyjnych pod względem inwestycyjnym obszarów nadmorskich w przypadku NOF Kołobrzeg przyjęła charakter pasmowo-węzłowy. Szczególnie intensywne zagospodarowywanie przestrzeni turystycznej zachodzi wzdłuż linii brzegowej na odcinku ponad 30 km. Rozwój Kołobrzegu jako ważnego ośrodka miejskiego z własnym miejskim obszarem funkcjonalnym prowadzi do silnej rozbudowy strefy podmiejskiej i powstawania tam licznych osiedli rezydencjonalnych (rys. 2). 


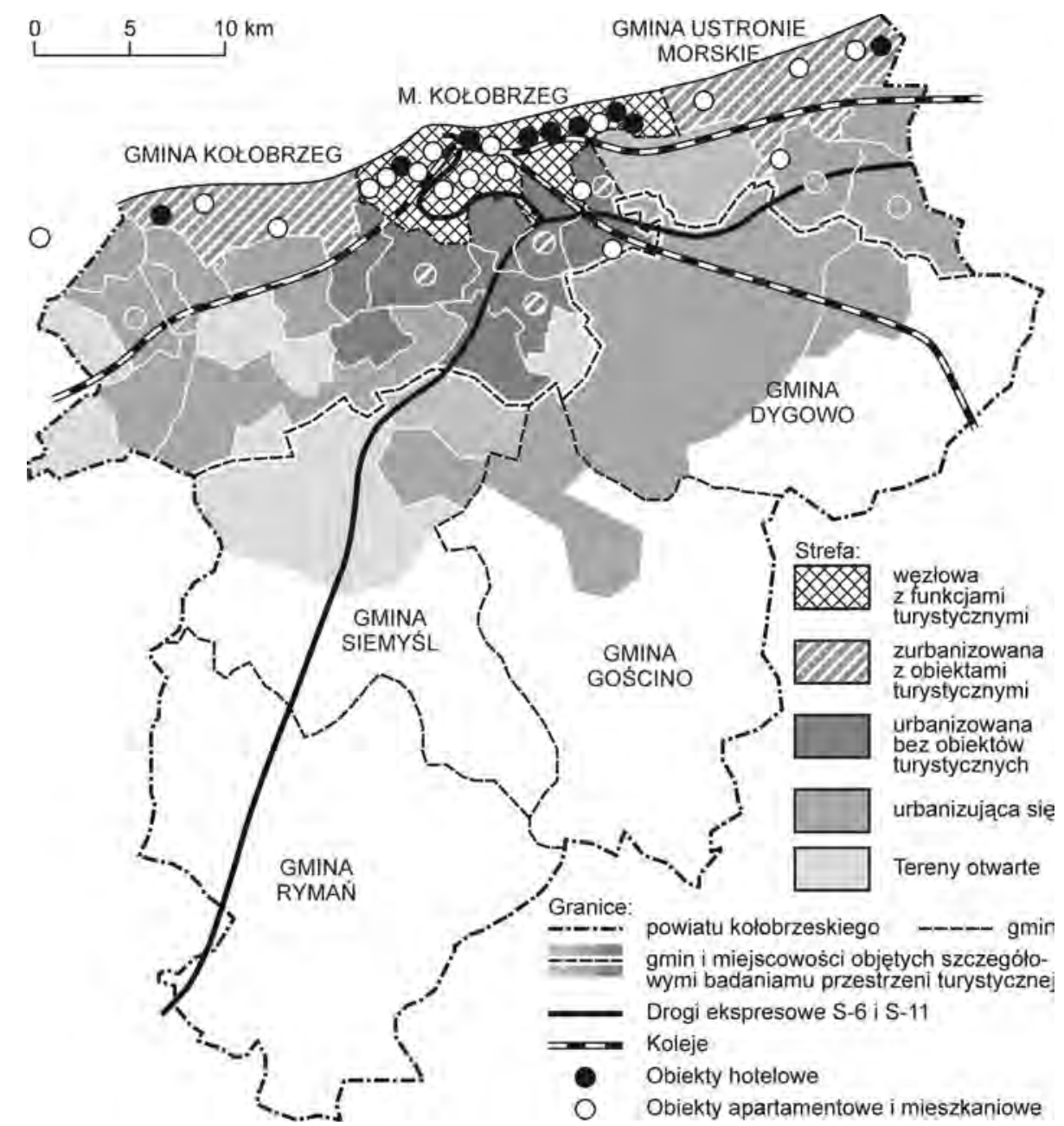

Rys. 2. Zaawansowanie procesów urbanizacyjnych w powiecie kołobrzeskim w NOF Kołobrzeg w latach 2010-2015 na tle układu komunikacyjnego

Źródło: opracowanie własne

Liczne nowe inwestycje mieszkaniowe, apartamentowe i hotelowe przygotowywane i budowane obecnie w NOF Kołobrzeg koncentrują się wzdłuż pasa nadmorskiego w najlepiej skomunikowanych rejonach strefy przybrzeżnej oraz w sąsiedztwie nowego układu komunikacyjnego (drogi ekspresowe S-6 i S-11) i innej infrastruktury transportowej (rys. 2).

$\mathrm{Na}$ podstawie rozpoczynanych, realizowanych i finalizowanych w 2016 r. inwestycji możliwe jest ustalenie pojemności tej nowej zabudowy mieszkaniowej i turystycznej. Założono, że na jeden pokój hotelowy przypadają średnio dwa miejsca noclegowe, a na każdy apartament, mieszkanie i dom jednorodzinny trzy osoby. W ciągu najbliższych 2-3 lat liczba ludności w nowej zabudowie mieszkaniowej może wzrosnąć o około 8,5 tys. osób, zaś liczba turystów w bazie noclegowej może zwiększyć się o kolejne 14 tys. (tab. 1).
Badania rozmieszczenia i skali przygotowywanych i realizowanych w latach 2016-2020 inwestycji pozwalają oszacować, że łączna liczba ludności i turystów w NOF Kołobrzeg może w ciągu 3-4 lat wzrosnąć łącznie o około 22,5 tys. osób. Wybudowanie 1700 mieszkań i 1200 domów jednorodzinnych pozwoli zwiększyć potencjał mieszkaniowy o około 8,5 tys. osób. Jednocześnie zbudowanie kolejnych 2000 pokoi hotelowych oraz 3300 apartamentów może dać aż 14 tys. nowych miejsc noclegowych. Obecna liczba ludności i osób czasowo tu zamieszkujących może zwiększyć się z 61 tys. do około 69 tys. Liczba miejsc noclegowych może w tym czasie wzrosnąć ze 104 tys. do 118 tys., co oznacza, że zaludnienie w okresie sezonu letniego może powiększyć się ze 164 tys. (2016 r.) do blisko 188 tys. w 2020 r. - po oddaniu do użytkowania wszystkich rozpoczynanych i realizowanych obecnie 
Tab. 1. Rozbudowa bazy noclegowej i zasobów mieszkaniowych orazszacowane zmiany liczby ludności i liczby turystów tworzących potencjał demograficzny NOF Kołobrzeg w 2016 r.

\begin{tabular}{|c|c|c|c|c|c|c|}
\hline \multirow[b]{2}{*}{ Jednostki NOF } & \multicolumn{4}{|c|}{ Baza noclegowa (liczba) } & \multicolumn{2}{|c|}{ Liczba osób } \\
\hline & $\begin{array}{c}\text { miesz- } \\
\text { kania }\end{array}$ & domy & $\begin{array}{c}\text { pokoje } \\
\text { hotelowe }\end{array}$ & $\begin{array}{c}\text { apar- } \\
\text { tamenty }\end{array}$ & $\begin{array}{l}\text { miesz- } \\
\text { kańcy }\end{array}$ & turyści \\
\hline Śródmieście & 250 & - & - & - & 750 & 0 \\
\hline Śródmieście - Zamoście & 700 & - & - & - & 2100 & 0 \\
\hline Śródmieście Południowe & 300 & - & - & 200 & 900 & 600 \\
\hline Dzielnica Zachodnia & 250 & - & - & 250 & 750 & 750 \\
\hline Zachodnia Dzielnica Uzdrowiskowa & - & - & 100 & 250 & 0 & 950 \\
\hline Zachodnia Centralna Dzielnica Uzdrowiskowa & - & - & 500 & 50 & 0 & 1150 \\
\hline Wschodnia Centralna Dzielnica Uzdrowiskowa & - & - & 450 & 50 & 0 & 1050 \\
\hline Wschodnia Dzielnica Uzdrowiskowa & - & - & 300 & 450 & 0 & 1950 \\
\hline Podczele & - & - & - & 250 & 0 & 750 \\
\hline Sianożęty & - & 25 & - & 225 & 75 & 675 \\
\hline Ustronie Morskie & - & 100 & 200 & 200 & 300 & 1000 \\
\hline Kukinka & - & 250 & - & - & 750 & 0 \\
\hline Dźwirzyno - Rogowo & - & 50 & 200 & 600 & 150 & 2200 \\
\hline Grzybowo & - & 50 & - & 200 & 150 & 600 \\
\hline Charzyno (przy granicy NOF) & - & 270 & - & - & 810 & 0 \\
\hline Rozproszone inwestycje indywidualne NOF Kołobrzeg & 200 & 450 & 300 & 600 & 1950 & 2400 \\
\hline Razem w budowie & 1700 & 1195 & 2050 & 3325 & 8685 & 14075 \\
\hline \multicolumn{7}{|l|}{ Stan obecny NOF Kołobrzeg } \\
\hline Mieszkańcy & 12000 & 8000 & - & - & 60000 & - \\
\hline Turyści & 10000 & 4000 & - & - & - & 42000 \\
\hline Turyści & - & - & 6500 & 8000 & - & 37000 \\
\hline Turyści (inna baza np. hotelowa) & - & - & 4500 & 5000 & - & 25000 \\
\hline Razem (2016 r.) & 22000 & 12000 & 11000 & 13000 & 60000 & 104000 \\
\hline Razem w budowie (2016 r.) & 1700 & 1195 & 2050 & 3325 & 8685 & 14075 \\
\hline Łącznie ok. 2020 r. & 23700 & 13195 & 13050 & 16325 & 68685 & 118075 \\
\hline $\begin{array}{l}\text { Eącznie } \\
\text { Suma }\end{array}$ & \multicolumn{2}{|c|}{$\begin{array}{c}\text { domy i mieszkania } \\
36895\end{array}$} & \multicolumn{2}{|c|}{$\begin{array}{c}\text { pokoje i apartamenty } \\
29375 \\
\end{array}$} & \multicolumn{2}{|c|}{$\begin{array}{c}\text { ludność i turyści } \\
186760\end{array}$} \\
\hline
\end{tabular}

- (-) zjawisko nie wystąpiło.

Źródło: opracowanie własne autora.

inwestycji (tab. 1). W przypadku kontynuacji połowy tylko z obecnego tempa przyrostu zasobów mieszkaniowych, apartamentowych i hotelowych na poziomie około 11 tys. osób w ciągu kolejnych pięciu lat możliwe jest osiągnięcie przez NOF Kołobrzeg sezonowego zaludnienia tego obszaru wynoszącego tu 210 tys. osób w 2030 r. i 235000 osób w 2040.

\section{WNIOSKI}

Obecne tempo rozwoju NOF Kołobrzeg, poprawa jego dostępności komunikacyjnej oraz duże możliwości rozwoju zabudowy mieszkaniowej, sanatoryjnej, hotelowej i apartamentowej w ciągu najbliższych 25 lat (do 2040 r.) wskazuje na klasyczny model rozwoju TALC opierający się na kilku podstawowych cechach rozwojowych. Można tu wymienić kluczowe czynniki rozwoju tworzące tzw. progowy cykl życia obszaru turystycznego (TTALC) (Miedziński 2015a).

1. Wyjątkowe walory przyrodnicze i leczniczo-uzdrowiskowe NOF Kołobrzeg są przyczyną nadzwyczajnej koncentracji funkcji uzdrowiskowych i wypoczynkowych.

2. Ten obszar turystyczny, będący największym obok Warszawy i Krakowa centrum ruchu turystycznego w Polsce (wg liczby osobonoclegów), powinien mieć możliwie najlepszą dostępność komunikacyjną transportem drogowym, kolejowym, morskim i lotniczym.

3. Wydłużenie trwania sezonu w kierunku całorocznego funkcjonowania przestrzeni turystycznej jest 
kluczem do dalszego rozwoju nowych funkcji turystycznych i usługowych, przy naczelnej pozycji turystyki uzdrowiskowo-wypoczynkowej.

4. Kolonizacja i urbanizacja turystyczna oraz rozwój zabudowy mieszkaniowej i apartamentowej z przebudową systemu komunikacyjnego muszą być tu realizowane przy bezwzględnym przestrzeganiu zasad ochrony środowiska i walorów uzdrowiskowych.

5. Obecne sezonowe zaludnienie NOF Kołobrzeg oraz możliwości jego dalszego rozwoju przestrzennego i społeczno-gospodarczego może doprowadzić do istotnych zagrożeń środowiskowych, przyrodniczych, funkcjonalnych i przestrzennych, które z kolei potencjalnie mogą spowodować poważne trudności $\mathrm{w}$ jego dalszym funkcjonowaniu.

6. Atrakcyjność inwestycyjna MOF Kołobrzeg dla dalszego rozwoju różnorodnych funkcji turystycznych jest przyczyną realizowania (i rozważania) kolejnych inwestycji komunikacyjnych. NOF Kołobrzeg jest obecnie na etapie przekraczania kolejnego progu rozwojowego.

7. Rozwój przestrzenny i funkcjonalny miasta Kołobrzeg i obu sąsiednich gmin prowadzi do ścisłej ich integracji, dzięki czemu możliwa jest zmiana granic miasta i utworzenie powiatu grodzkiego Kołobrzeg w granicach obecnego NOF.

8. Obecne tempo procesów kolonizacyjnych i urbanizacyjnych NOF Kołobrzeg może doprowadzić do powstania drugiego obok Trójmiasta największego nadmorskiego obszaru zurbanizowanego na polskim wybrzeżu Morza Bałtyckiego.

9. W perspektywie najbliższych 25 lat (ok. 2040 roku) Kołobrzeg i jego największa w Polsce uzdrowiskowa przestrzeń turystyczna może osiągnąć poziom 75 tys. mieszkańców i rezydentów, a liczba turystów w sezonie może sięgnąć 160 tys. osób.

10. Kołobrzeg i jego Nadmorski Obszar Funkcjonalny jest drugim po Trójmieście największym przestrzennie obszarem zurbanizowanym polskiego wybrzeża, a względy demograficzne i społeczno-gospodarcze wskazują na potrzebę zaliczenia tego miasta do ośrodków o znaczeniu regionalnym, na równi z Koszalinem i Słupskiem.

\section{BIBLIOGRAFIA}

Franek Ł., 2015, Polityka transportowa Nadmorskiego Obszaru Funkcjonalnego obejmującego gminę miasto Kołobrzeg, gminę Kołobrzeg i gminę Ustronie Morskie, Stowarzyszenie Inżynierów i Techników Komunikacji, Kraków, ss. 124.

Komornicki T., 2015, Dostępność przestrzenna polskich portów morskich. Opracowanie eksperckie dla Instytutu Morskiego ${ }_{w}$ Gdańsku, IGiPZ PAN, Warszawa, ss. 46.

Kozłowski J., 1974, Analiza progowa, Prace Instytutu Kształtowania Środowiska, PWN, Warszawa, ss. 101.

Lider Projekt, 2014, Strategia rozwoju Nadmorskiego Obszaru Funkcjonalnego obejmującego gminę miasto Kołobrzeg, gminę Koobrzeg oraz gminę Ustronie Morskie, Wrocław, ss. 115.

Malisz B., 1971, Metoda analizy progowej w zastosowaniu do planowania miast i regionów, [w:] B. Malisz, J. Żurkowski (red.), Metoda analizy progowej, Studia KPZK PAN, 34, Warszawa, s. 27-47.

Miedziński M., 2012a, Miasto Kołobrzeg wiodącym uzdrowiskiem Polski i jednym z centrów turystycznych kraju, [w:] E. Rydz (red.), Ekonomiczne i organizacyjne aspekty funkcjonowania polskich uzdrowisk, Wyd. AP, Słupsk, s. 139-150.

Miedziński M., 2012b, Możliwości zmiany granic administracyjnych miasta Kołobrzeg w kontekście jego rozwoju przestrzennego i funkcjonalnego, „Słupskie Prace Geograficzne”, s. 99-108.

Miedziński M., 2015a, The creation of the model Threshold Tourist Area Life Cycle of the functional urban area of Kołobrzeg [Tworzenie modelu progowego cyklu życia obszaru turystycznego na przykładzie miejskiego obszaru funkcjonalnego Kołobrzeg], „Economic Problems of Tourism”, 877, 4 (32), s. $45-62$.

Miedziński M., 2015b, Rozwój przestrzeni turystycznej i układu komunikacyjnego Nadmorskiego Obszaru Funkcjonalnego Kołobrzeg - zarys historyczny - stan obecny - perspektywy, „Stupskie Prace Geograficzne", 12, s. 105-121.

„Program budowy dróg krajowych na lata 2015-2023 z perspektywą do 2030 r.”, założenia do Uchwały nr 156/2015 Rady Ministrów z 8 września 2015 r., Warszawa, ss. 50.

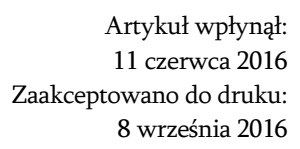

Artykuł wpłyną: wano do druku: 